\title{
On Materializing the Conceptual Framework for e-Learning: A Pilot Study
}

\author{
Su-Kheng Haw*, Chee-Onn Wong and Yan-Peng Lim \\ Faculty of Creative Multimedia, Jalan Multimedia, 63100 Cyberjaya, Malaysia; \\ sukheng79@gmail.com,cowong@mmu.edu.my, forest.lim@mmu.edu.my
}

\begin{abstract}
Background/Objectives: A conceptual framework is essential to ensure that the Critical Success Factors (CSFs) for e-Learning implementation is clearly identified to minimize the failure risk. Methods/Statistical Analysis: LearnCube is a conceptual framework proposed to model the CSF in multi-dimensional model. In this paper, we materialized the LearnCube framework to demonstrate that the model covers all the aspect of CSFs accurately. Findings: A pilot study has been conducted and the results agreed that the identified factors have significant influence on the success of EL implementation. In this research, a survey questionnaire is used as the research instrument to collect information due to its inexpensive, efficient, and precise mechanism of data collection. The sampling of respondents is based on purposive sampling, whereby the respondents were selected from the specific group (secondary school students) which is able to provide the data needed for this research. Application/Improvements: The results agreed that the identified factors have significant influence on the success of EL implementation especially on the secondary school based on Economic Asas curriculum.
\end{abstract}

Keywords: Pilot Study, Critical Success Factors, Conceptual Framework, Secondary School, e-Learning Implementation,

\section{Introduction}

Many universities and higher learning institutions has adopted e-Learning (EL) in their teaching mode. There has been an increasing number of Course Management Systems (CMSs) and Virtual Learning Environment (VLE) developed and used (e.g. Blackboard and Moodle) to facilitate the learning and teaching activities. Since EL offers a learning environment which transcends spatial and temporal restrictions, its usage has been continuously increasing every year. Yet, this technology has not been fully implemented especially in secondary school.

Most of the secondary schools are still using traditional delivering method. This refers to the pedagogy involves in delivering the contents of the syllabus to students. For example, most teachers merely based on the hardcopy of textbook and give short notes to the students, or while reading the textbook, requesting the students to highlight part of the notes and so on. Using any multimedia or information technology to collaborate is very limited.

Nevertheless, the failure percentage for EL implementation is still relatively high $\frac{1-3}{}$. This may be due to improper identification on the CSFs, and henceforth, the failure to model the comprehensive EL framework appropriately. As such, this paper first objective is review the existing conceptual framework in EL domain. In addition, we briefly discuss on the proposed conceptual framework, LearnCube ${ }^{4}$. The aim of this paper is to materialize LearnCube for the pilot implementation of EL. 
The rest of the paper is organized as follows. Section 2 reviews some related works on EL frameworks. In Section 3, we propose our framework. Section 4 is the core of this paper, whereby we describe the pilot study, which includes the objectives, experiment subjects, questionnaire design, and findings and analysis. Finally, Section 5 concludes the paper and suggests some future works.

\section{Background and Related Works}

\subsection{Background on Conceptual Framework}

The first EL framework was proposed ${ }^{5}$ in year 2001 . In his framework, he has identified the eight dimensions contributing to the success of EL implementation. These dimensions are institutional, pedagogical, technological, interface design, evaluation, management, resource support, and ethical. The institutional dimension covers the administrative matter, student services, and academic matter. The pedagogical deals with teaching and learning process, while the technological is referring to the technology support of the system. On the other hand, interface design governs matter related to the EL systems such as the input-output, graphical user interface and so on. The other identified dimensions are evaluation, which deals with assessment and evaluation, management, which governs the managing and maintenance of systems, and resource support, which governs the support for online. On top of this, ethical is necessary to deals with any social and cultural issues. From this framework, many other researchers have emerged with other conceptual framework to suit their current's need.

lidentified six dimensions, namely, Learner, Instructor, Course, Technology, Design and Environment as important factors for their proposed framework. In Learner dimension, learner attitude towards computers has significant influences on the level of acceptance on EL. In Instructor dimension, it is believed that timely responses from the instructors have significant impact on learners' satisfaction. In the Course dimension, the flexibility such as time, location, method, participation and satisfaction is the main concern. In the technology dimension however, the Internet quality, good infrastructure, and adequate equipments contributed to the success of EL implementation, while in the Design dimension, it is perceived usefulness and perceived easy of use. Lastly, in the Environmental dimension, a proper feedback mechanism is essential to e-Learners.
${ }_{6}^{6}$ proposed an EL framework for teachers to ensure effective e-interaction with students. They have identified eight main factors for EL, which are student, teacher, technology, course, institution, support, costs and society. In contrast to the earlier approaches, in addition to the enabling measurable, they also considered the disabling measurable based on these factors. Among some of the measurable are academic confidences, technological confidences, learning styles, curriculum design, subject content, availability of educational resources, rules and regulations and so on.

${ }^{7}$ presented their EL theoretical framework based on three main components that interact with the systems. These components are people, technologies, and services. People are the main drive of system, while technologies enable communication within the system, and consequently, services integrate all the teaching and learning process. Part of their proposed framework was extended from the work ${ }^{8}$. Hence, in addition to the three components described above, their model also incorporated the pedagogical models, instructional strategies, and learning technologies. The pedagogical models are concern with the type of learning environment such as open or distributed learning. The instructional strategies are activities such as contextualizing, presentation, instructional lesson, problem solving and cueing and so on, while the learning technologies are concern with content, communication (social network, forum, chat) and collaboration setup (sharing tool, one-to-one mentoring).

Table 1 summarizes the framework reviewed thus far in terms of the identified factors, scope, and features.

\subsection{Related Works}

${ }^{9}$ compared the performance of the students based on online and traditional classroom for the English subject. In their test, the students do not know in advanced which method of delivery will taught. The results showed that online students improved their scores. Nevertheless, the result is not significantly enough to draw a solid conclusion that one method is superior to the other.

${ }^{10}$ studied the impact of teaching and learning in Digital Age Web 2.0 via Classroom. They studied using Facebook as the teaching platform. Their study revealed that younger students are more familiar with the Internet and Web 2.0 technologies. As such, they are more receptive to accepting and benefiting from the use of Facebook in their classroom communities. 
Table 1. Summary on some frameworks for EL

\begin{tabular}{|c|c|c|c|c|}
\hline Framework & Khan $(2001)^{\underline{5}}$ & Sun et al. $(2008)^{1}$ & Tirziu \& Vrabie $(2015)^{6}$ & Aparicio et al. $(2016)^{\underline{7}}$ \\
\hline Identified Factors & $\begin{array}{l}\text { institutional, pedagogical, } \\
\text { technological, interface } \\
\text { design, evaluation, } \\
\text { management, resource } \\
\text { support, ethical } \\
\text { (8 dimensions) }\end{array}$ & $\begin{array}{l}\text { Learner, Instructor, } \\
\text { Course, Technology, } \\
\text { Design and } \\
\text { Environment } \\
\text { ( } 6 \text { dimensions) }\end{array}$ & $\begin{array}{l}\text { student, teacher, } \\
\text { technology, course, } \\
\text { institution, support, } \\
\text { costs, society } \\
\text { (8 dimensions) }\end{array}$ & $\begin{array}{l}\text { people, technologies, and } \\
\text { services } \\
\text { ( } 3 \text { dimensions) }\end{array}$ \\
\hline Scope & Tertiary & Tertiary & Tertiary & Tertiary \\
\hline Features & $\begin{array}{l}\text { Factors and dimensions of } \\
\text { E-Learning environment }\end{array}$ & $\begin{array}{l}\text { Critical success } \\
\text { factors for e-Learner } \\
\text { Satisfaction }\end{array}$ & $\begin{array}{l}\text { Enabling and disabling } \\
\text { factors for effective } \\
\text { e-interaction with } \\
\text { students }\end{array}$ & $\begin{array}{l}\text { Focus on the main } \\
\text { components that interact } \\
\text { with the system. }\end{array}$ \\
\hline
\end{tabular}

${ }^{11}$ proposed a usability framework to evaluate the use of multimedia element to aid Form 4 secondary school students to understand some of the Physics modules. They also evaluated the usability of the framework from students' retrospective evaluation. Their study indicated that Physics module based on learning style has its positive impacts on students' interest towards learning Physics. Subsequently, they also proposed that the school curriculum should include the computer enhanced modules instead of based solely on textbook.

\section{LearnCube: A Proposed Conceptual Framework}

Theoretical framework serves as the foundation of research by providing a specific perspective to examine a study ${ }^{12}$. Based on the previous researches reviewed in Section 2, a framework named LearnCube ${ }^{4}$ is proposed as depicted in Figure 1. In the framework, eighteen attributes are identified within the six dimensions as they are closely related to each other. For example, under Student's dimension, the measures are associated with student motivation (self-efficacy is individuals' inclination toward a particular functional aspect), student attitude (Positive attitudes toward computers increase the chances of successful computer learning) and also peer influence (Positive interaction of student-student interaction using computer learning). Nevertheless, the focus on this paper is on the pilot study of the implemented model. In addition, we propose our hypotheses for testing their relationships, which will be presented in this section.

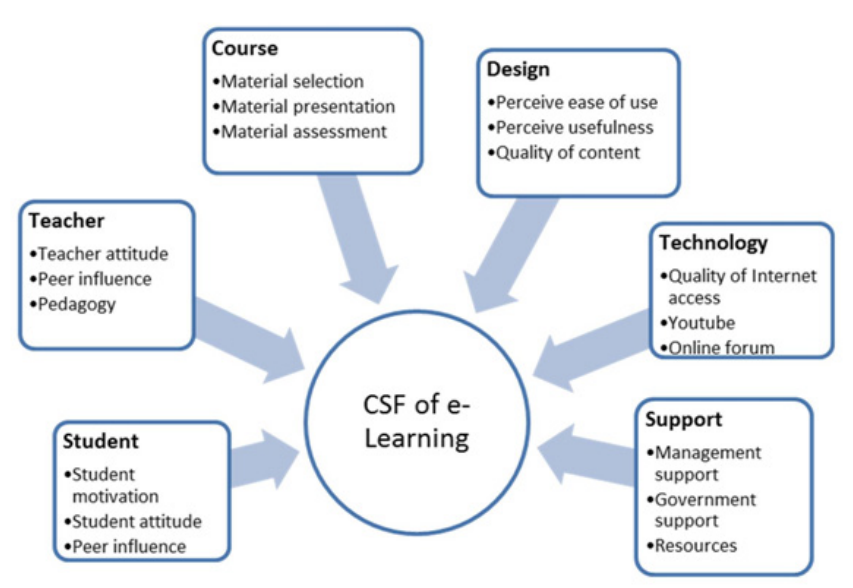

Figure 1. LearnCube framework.

\section{Implementation of LearnCube: A Pilot Study}

\subsection{Objectives}

Our objective is to identify the CSFs for the EL implementation in secondary school. In order to achieve this, we have implemented the LearnCube $e^{4}$ framework.

We test the null and alternative hypothesizes as stated:

Ho - There is no significant difference on the CSFs for the success implementation of EL in secondary school.

H1 - There is a difference on the CSFs for the success implementation of EL in secondary school. 


\subsection{Experiment Subjects, Sampling Size and Technique}

In this research, sampling of respondents is based on purposive sampling, whereby the sample involves the specific selection of respondents who are in the best position to provide the data needed $\frac{12}{}$. The sample will consist of secondary school students taking Economic Asas subject at a school named Sekolah Menengah Jenis Kebangsaan (SMJK) Kwang Hua located in Klang, Malaysia. Participants of the study were collected on 80 students.

\subsection{Questionnaire Design}

In this research, a survey questionnaire is used as the research instrument to collect information due to its inexpensive, efficient, and precise mechanism of data collection $\frac{12}{2}$. The questionnaire design is critical for it leads to collecting precise data in order to test the proposed hypotheses to support or refute theoretical propositions.

The breakdown on the questionnaire is as follows. A total of 46 questions were constructed with four sections. Section 1 and 2 are on general responding with few choices to choose (for demographic analysis). In Section 3 and 4 however, is combination of 32 questions with LIKERT scale mark. Participants were required to indicate the level of agreement on a 5-point LIKERT interval scale which was $1=$ strongly disagree, $2=$ disagree, $3=$ neutral, $4=$ agree and $5=$ strongly agree.

\subsection{Data Collection and Data Analysis Method}

The self-administered questionnaires were distributed to the respondents. A self-administered questionnaire refers to "a data collection technique in which the respondents reads the survey questions and records his/her responses without the presence of the trained interviewer" ${ }^{\prime 13} .{ }^{14} \mathrm{men}$ tioned that "considerable evidence suggests that people are more likely to give honest answers to self-administered than to interview questions".

After the data had been collected, the descriptive statistics (percentages and tables) were conducted using Statistical Package for Social Science (SPSS) version 22. The mean scores and the standard deviation were calculated. Additionally, we also investigate on the demographic variables, whereby an estimate of the response percentages and frequencies was also made.

\subsection{Findings and Analysis}

The sampling of respondents is based on purposive sampling, whereby the respondents were selected from the specific group (secondary school students) which is able to provide the data needed for this research. The respondents' demographic profile is depicted in Table 1.

Table 1 shows the student demographics including their gender $(62.5 \%$ were Female, while $37.5 \%$ were Male), year in school (level of study) and age group. From Table 2, we observed that 100\% were in Form 4 (level 1 of study) while $0 \%$ were in Form 5 (level 2 of study). In terms of the frequency of using electronic devices. $23.8 \%$ uses electronic devices once per week, $15 \%$ uses the devices 2 - 3 times a week, $11.3 \%$ uses $4-5$ times a week, while 50\% uses it more than or greater than 6 times per week.

Table 1. Demographic of the respondents

\begin{tabular}{|c|c|c|}
\hline Item & Frequency & Percentage \% \\
\hline \multicolumn{3}{|l|}{ Gender } \\
\hline Male & 30 & 37.5 \\
\hline Female & 50 & 62.5 \\
\hline Total & 80 & 100 \\
\hline \multicolumn{3}{|c|}{ Level of study (Years in School) } \\
\hline Form 4 & 0 & 0 \\
\hline Form 5 & 80 & 100 \\
\hline Total & 80 & 100 \\
\hline \multicolumn{3}{|l|}{ Age group } \\
\hline 16 & 7 & 8.8 \\
\hline 17 & 71 & 88.8 \\
\hline 18 & 2 & 2.5 \\
\hline Total & 80 & 100 \\
\hline \multicolumn{3}{|c|}{ Frequency usage of electronic devices } \\
\hline Once a week & 19 & 23.8 \\
\hline $2-3$ times a week & 12 & 15.0 \\
\hline $4-5$ times a week & 9 & 11.3 \\
\hline$>=6$ times a week & 40 & 50 \\
\hline Total & 80 & 100 \\
\hline
\end{tabular}

In order to identify which of the indicated factors are perceived to be crucial for the success of EL implementation, the level of agreement and the mean were used.

Table 2 shows the descriptive statistic on the Students' Dimension. From the analysis, it revealed that students' characteristics are critical factors of EL. Student motivation came in first place among the other attributes, with 
Table 2. Descriptive statistic of the students' dimension

\begin{tabular}{|c|c|c|c|c|c|c|c|c|}
\hline \multirow[t]{2}{*}{ Attributes } & \multirow[t]{2}{*}{ Statement } & \multicolumn{6}{|c|}{ Likert Scale } & \multirow[t]{2}{*}{ Mean } \\
\hline & & $\begin{array}{c}\text { Number/ } \\
\%\end{array}$ & $\begin{array}{l}\text { Strongly } \\
\text { disagree }\end{array}$ & disagree & neutral & agree & $\begin{array}{c}\text { Strongly } \\
\text { agree }\end{array}$ & \\
\hline \multirow{3}{*}{$\begin{array}{l}\text { Student } \\
\text { motivation }\end{array}$} & The integration of EL into & Number & 0 & 0 & 4 & 39 & 37 & 4.4125 \\
\hline & $\begin{array}{l}\text { traditional method is more } \\
\text { encouraging than the } \\
\text { traditional method alone. }\end{array}$ & $\%$ & 0 & 0 & 5 & 48.8 & 46.3 & \\
\hline & $\begin{array}{l}\text { The integration of EL into } \\
\text { traditional method is more } \\
\text { lively and dynamic than ever } \\
\text { before. }\end{array}$ & $\begin{array}{c}\text { Number } \\
\%\end{array}$ & $\begin{array}{l}0 \\
0\end{array}$ & $\begin{array}{l}0 \\
0\end{array}$ & $\begin{array}{c}3 \\
3.8\end{array}$ & $\begin{array}{l}12 \\
15\end{array}$ & $\begin{array}{c}65 \\
81.3\end{array}$ & 4.7750 \\
\hline $\begin{array}{l}\text { Student } \\
\text { attitude }\end{array}$ & $\begin{array}{l}\text { The use of EL provides more } \\
\text { opportunities to participate } \\
\text { in activities (including } \\
\text { activities involving classmates } \\
\text { such as question solving, } \\
\text { group assignment) than the } \\
\text { traditional method alone. }\end{array}$ & $\begin{array}{c}\text { Number } \\
\%\end{array}$ & $\begin{array}{l}0 \\
0\end{array}$ & $\begin{array}{c}1 \\
1.3\end{array}$ & $\begin{array}{c}3 \\
3.8\end{array}$ & $\begin{array}{l}44 \\
55\end{array}$ & $\begin{array}{l}32 \\
40\end{array}$ & 4.3375 \\
\hline \multirow[t]{2}{*}{$\begin{array}{l}\text { Peer } \\
\text { Influence }\end{array}$} & $\begin{array}{l}\text { With the EL integrated into } \\
\text { the traditional learning, I have } \\
\text { more opportunity to learn from } \\
\text { / interact with my classmates. }\end{array}$ & $\begin{array}{c}\text { Number } \\
\%\end{array}$ & $\begin{array}{l}0 \\
0\end{array}$ & $\begin{array}{c}2 \\
2.5\end{array}$ & $\begin{array}{c}3 \\
3.8\end{array}$ & $\begin{array}{c}21 \\
26.3\end{array}$ & $\begin{array}{c}54 \\
67.5\end{array}$ & 4.5875 \\
\hline & TOTAL & & & & & & & 18.112 \\
\hline
\end{tabular}

Table 3. Descriptive statistic of the teachers' dimension

\begin{tabular}{|c|c|c|c|c|c|c|c|c|}
\hline \multirow[t]{2}{*}{ Attributes } & \multirow[t]{2}{*}{ Statement } & \multicolumn{6}{|c|}{ Likert Scale } & \multirow[b]{2}{*}{ Mean } \\
\hline & & $\begin{array}{c}\text { Number/ } \\
\%\end{array}$ & $\begin{array}{l}\text { Strongly } \\
\text { disagree }\end{array}$ & disagree & neutral & agree & $\begin{array}{c}\text { Strongly } \\
\text { agree }\end{array}$ & \\
\hline \multirow[t]{2}{*}{$\begin{array}{l}\text { Teacher } \\
\text { Attitude }\end{array}$} & $\begin{array}{l}\text { The integration of EL into } \\
\text { traditional method is motivated } \\
\text { as having more chance to } \\
\text { interact with teacher virtually }\end{array}$ & $\begin{array}{c}\text { Number } \\
\%\end{array}$ & $\begin{array}{l}0 \\
0\end{array}$ & $\begin{array}{c}1 \\
1.3\end{array}$ & $\begin{array}{c}3 \\
3.8\end{array}$ & $\begin{array}{c}19 \\
23.8\end{array}$ & $\begin{array}{c}57 \\
71.3\end{array}$ & 4.6500 \\
\hline & $\begin{array}{l}\text { Teachers are more confident } \\
\text { in their teaching as they are } \\
\text { able to show the demo/video } \\
\text { clips to enhance the student } \\
\text { understanding or certain } \\
\text { modules }\end{array}$ & $\begin{array}{c}\text { Number } \\
\%\end{array}$ & $\begin{array}{l}0 \\
0\end{array}$ & $\begin{array}{l}0 \\
0\end{array}$ & $\begin{array}{c}2 \\
2.5\end{array}$ & $\begin{array}{c}21 \\
26.3\end{array}$ & $\begin{array}{c}57 \\
71.3\end{array}$ & 4.6875 \\
\hline $\begin{array}{l}\text { Peer } \\
\text { influence }\end{array}$ & $\begin{array}{l}\text { The use of eLearning } \\
\text { provides more opportunities } \\
\text { to participate in activities } \\
\text { (including teacher responding } \\
\text { to questions efficiently } \\
\text { virtually, without the need of } \\
\text { having face to face meeting) }\end{array}$ & $\begin{array}{c}\text { Number } \\
\%\end{array}$ & $\begin{array}{c}1 \\
1.3\end{array}$ & $\begin{array}{c}1 \\
1.3\end{array}$ & $\begin{array}{c}12 \\
15.0\end{array}$ & $\begin{array}{c}52 \\
65.0\end{array}$ & $\begin{array}{c}14 \\
17.5\end{array}$ & 3.9625 \\
\hline \multirow[t]{2}{*}{ Pedagogy } & $\begin{array}{l}\text { Using both teaching method } \\
\text { learning shift the teaching } \\
\text { - learning process to the } \\
\text { student-centered approach. }\end{array}$ & $\begin{array}{c}\text { Number } \\
\%\end{array}$ & $\begin{array}{l}0 \\
0\end{array}$ & $\begin{array}{l}0 \\
0\end{array}$ & $\begin{array}{c}5 \\
6.3\end{array}$ & $\begin{array}{c}43 \\
53.8\end{array}$ & $\begin{array}{c}32 \\
40.0\end{array}$ & 4.3375 \\
\hline & TOTAL & & & & & & & 17.6375 \\
\hline
\end{tabular}


the average mean score of 4.59, followed by Peer Influence and Student Attitude respectively. The ratings for the all the sub-items of this factor was 18.11 . The results indicated that participants agreed with the survey statements.

Table 3 shows the descriptive statistic on the Teachers' Dimension. From the analysis, it revealed that teachers' characteristics are critical factors of EL. The Teacher Attitude attributed to the highest ranking, followed by Pedagogy, and Peer Influence respectively.
The ratings for the all the sub-items of this factor was 17.63. On the other hand, Table 4 depicts the descriptive statistic on the Course Dimension. From the analysis, it revealed Material Assessment has the highest ranking, followed by Material Presentation, and Material Selection respectively. The ratings for the all the sub-items of this factor was 16.83 .

The rest of the tables, Table 5, 6 and 7 show the descriptive statistics on the Design, Technology and Support

Table 4. Descriptive statistic of the courses' dimension

\begin{tabular}{|c|c|c|c|c|c|c|c|c|}
\hline \multirow[t]{2}{*}{ Attributes } & \multirow[t]{2}{*}{ Statement } & \multicolumn{7}{|c|}{ Likert Scale } \\
\hline & & $\begin{array}{c}\text { Number/ } \\
\%\end{array}$ & $\begin{array}{l}\text { Strongly } \\
\text { disagree }\end{array}$ & disagree & neutral & agree & $\begin{array}{l}\text { Strongly } \\
\text { agree }\end{array}$ & Mean \\
\hline \multirow{3}{*}{$\begin{array}{l}\text { Material } \\
\text { Selection }\end{array}$} & Integration of eLearning and & Number & 0 & 0 & 10 & 47 & 23 & 4.1625 \\
\hline & $\begin{array}{l}\text { traditional teaching teaching } \\
\text { can be used effectively in } \\
\text { teaching Basic Economic. }\end{array}$ & $\%$ & 0 & 0 & 12.5 & 58.8 & 28.7 & \\
\hline & $\begin{array}{l}\text { Using both technologies, I } \\
\text { am able to select my learning } \\
\text { materials effectively }\end{array}$ & $\begin{array}{c}\text { Number } \\
\%\end{array}$ & $\begin{array}{l}0 \\
0\end{array}$ & $\begin{array}{l}0 \\
0\end{array}$ & $\begin{array}{c}9 \\
11.3\end{array}$ & $\begin{array}{c}45 \\
56.3\end{array}$ & $\begin{array}{c}26 \\
32.5\end{array}$ & 4.2125 \\
\hline $\begin{array}{l}\text { Material } \\
\text { Presentation }\end{array}$ & $\begin{array}{l}\text { Using both technologies, I am } \\
\text { able to present my assignment/ } \\
\text { homework effectively }\end{array}$ & $\begin{array}{c}\text { Number } \\
\%\end{array}$ & $\begin{array}{l}0 \\
0\end{array}$ & $\begin{array}{l}0 \\
0\end{array}$ & $\begin{array}{c}5 \\
6.3\end{array}$ & $\begin{array}{c}54 \\
67.5\end{array}$ & $\begin{array}{c}21 \\
26.3\end{array}$ & 4.2000 \\
\hline \multirow[t]{2}{*}{$\begin{array}{l}\text { Material } \\
\text { Assessment }\end{array}$} & $\begin{array}{l}\text { I think that teaching with } \\
\text { merging some technology such } \\
\text { as slide show would improve } \\
\text { my learning skill for the subject } \\
\text { of Basic Economic }\end{array}$ & $\begin{array}{c}\text { Number } \\
\%\end{array}$ & $\begin{array}{l}0 \\
0\end{array}$ & $\begin{array}{l}0 \\
0\end{array}$ & $\begin{array}{c}5 \\
6.3\end{array}$ & $\begin{array}{c}49 \\
61.3\end{array}$ & $\begin{array}{c}26 \\
32.5\end{array}$ & 4.2625 \\
\hline & TOTAL & & & & & & & 16.8375 \\
\hline
\end{tabular}

Table 5. Descriptive statistic of the designs' dimension

\begin{tabular}{|c|c|c|c|c|c|c|c|c|}
\hline \multirow[t]{2}{*}{ Attributes } & \multirow[t]{2}{*}{ Statement } & \multicolumn{6}{|c|}{ Likert Scale } & \multirow[b]{2}{*}{ Mean } \\
\hline & & $\begin{array}{c}\text { Number/ } \\
\%\end{array}$ & $\begin{array}{l}\text { Strongly } \\
\text { disagree }\end{array}$ & disagree & neutral & agree & $\begin{array}{c}\text { Strongly } \\
\text { agree }\end{array}$ & \\
\hline \multirow{2}{*}{$\begin{array}{l}\text { Perceive } \\
\text { ease of use }\end{array}$} & \multirow{2}{*}{$\begin{array}{l}\text { I feel more interested while using the } \\
\text { integration eLearning and traditional } \\
\text { teaching approaches }\end{array}$} & Number & 0 & 0 & 8 & 56 & 16 & 4.1000 \\
\hline & & $\%$ & 0 & 0 & 10.0 & 70.0 & 20.0 & \\
\hline \multirow[t]{2}{*}{$\begin{array}{l}\text { Perceive } \\
\text { usefulness }\end{array}$} & $\begin{array}{l}\text { I would like to see my notes colourful, } \\
\text { visualize rather than just black and white }\end{array}$ & $\begin{array}{c}\text { Number } \\
\%\end{array}$ & $\begin{array}{l}0 \\
0\end{array}$ & $\begin{array}{c}1 \\
1.3\end{array}$ & $\begin{array}{c}1 \\
1.3\end{array}$ & $\begin{array}{l}16 \\
20\end{array}$ & $\begin{array}{c}62 \\
77.5\end{array}$ & 4.7375 \\
\hline & $\begin{array}{l}\text { I prefer digital homework which is access } \\
\text { to an electronic device, then launch the } \\
\text { homework and click the answer }\end{array}$ & $\begin{array}{l}\text { Number } \\
\%\end{array}$ & $\begin{array}{l}0 \\
0\end{array}$ & $\begin{array}{l}0 \\
0\end{array}$ & $\begin{array}{c}2 \\
2.5\end{array}$ & $\begin{array}{c}42 \\
52.5\end{array}$ & $\begin{array}{l}36 \\
45\end{array}$ & 4.4250 \\
\hline \multirow[t]{2}{*}{$\begin{array}{l}\text { Quality of } \\
\text { content }\end{array}$} & $\begin{array}{l}\text { Having eLearning integrated, it improves } \\
\text { the quality of content, learning and } \\
\text { teaching process }\end{array}$ & $\begin{array}{l}\text { Number } \\
\%\end{array}$ & $\begin{array}{l}0 \\
0\end{array}$ & $\begin{array}{c}1 \\
1.3\end{array}$ & $\begin{array}{c}6 \\
7.5\end{array}$ & $\begin{array}{c}43 \\
53.8\end{array}$ & $\begin{array}{c}30 \\
37.5\end{array}$ & 4.2750 \\
\hline & TOTAL & & & & & & & 17.5375 \\
\hline
\end{tabular}


Table 6. Descriptive statistic of the techonologies' dimension

\begin{tabular}{|c|c|c|c|c|c|c|c|c|}
\hline \multirow[t]{2}{*}{ Attributes } & \multirow[t]{2}{*}{ Statement } & \multicolumn{6}{|c|}{ Likert Scale } & \multirow[b]{2}{*}{ Mean } \\
\hline & & $\begin{array}{c}\text { Number/ } \\
\%\end{array}$ & $\begin{array}{l}\text { Strongly } \\
\text { disagree }\end{array}$ & disagree & neutral & agree & $\begin{array}{c}\text { Strongly } \\
\text { agree }\end{array}$ & \\
\hline \multirow[t]{3}{*}{$\begin{array}{l}\text { Quality of } \\
\text { Internet access }\end{array}$} & $\begin{array}{l}\text { Having eLearning materials } \\
\text { online } 24 / 7 \text { is practical for } \\
\text { learning and teaching process }\end{array}$ & $\begin{array}{c}\text { Number } \\
\%\end{array}$ & $\begin{array}{c}1 \\
1.3\end{array}$ & $\begin{array}{l}0 \\
0\end{array}$ & $\begin{array}{c}5 \\
6.3\end{array}$ & $\begin{array}{c}30 \\
37.5\end{array}$ & $\begin{array}{l}44 \\
55\end{array}$ & 4.4500 \\
\hline & $\begin{array}{l}\text { Getting hook up to the Internet } \\
\text { is easy nowadays with WiFi } \\
\text { signal available most of the } \\
\text { places }\end{array}$ & $\begin{array}{c}\text { Number } \\
\%\end{array}$ & $\begin{array}{l}0 \\
0\end{array}$ & $\begin{array}{l}0 \\
0\end{array}$ & $\begin{array}{c}5 \\
6.3\end{array}$ & $\begin{array}{c}14 \\
17.5\end{array}$ & $\begin{array}{c}61 \\
76.3\end{array}$ & 4.7000 \\
\hline & $\begin{array}{l}\text { I would like to learn the } \\
\text { concept and skill during my } \\
\text { own free time with eLearning } \\
\text { using my gadgets such as } \\
\text { laptop, smartphone or tablets }\end{array}$ & $\begin{array}{c}\text { Number } \\
\%\end{array}$ & $\begin{array}{l}0 \\
0\end{array}$ & $\begin{array}{c}2 \\
2.5\end{array}$ & $\begin{array}{c}6 \\
7.5\end{array}$ & $\begin{array}{c}17 \\
21.3\end{array}$ & $\begin{array}{c}55 \\
68.8\end{array}$ & 4.5625 \\
\hline YouTube & \multirow{2}{*}{$\begin{array}{l}\text { Website such as YouTube and } \\
\text { online forum provide useful } \\
\text { and reliable information to aid } \\
\text { my study }\end{array}$} & \multirow[t]{2}{*}{$\begin{array}{c}\text { Number } \\
\%\end{array}$} & \multirow[t]{2}{*}{$\begin{array}{l}0 \\
0\end{array}$} & \multirow[t]{2}{*}{$\begin{array}{c}1 \\
1.3\end{array}$} & \multirow[t]{2}{*}{$\begin{array}{c}3 \\
3.8\end{array}$} & \multirow[t]{2}{*}{$\begin{array}{c}8 \\
10\end{array}$} & \multirow[t]{2}{*}{$\begin{array}{c}67 \\
83.8\end{array}$} & \multirow[t]{2}{*}{5.0000} \\
\hline Online Forum & & & & & & & & \\
\hline & TOTAL & & & & & & & 18.7125 \\
\hline
\end{tabular}

Table 7. Descriptive statistic of the supports' dimension

\begin{tabular}{|c|c|c|c|c|c|c|c|c|}
\hline \multirow[t]{2}{*}{ Attributes } & \multirow[t]{2}{*}{ Statement } & \multicolumn{6}{|c|}{ Likert Scale } & \multirow[b]{2}{*}{ Mean } \\
\hline & & $\begin{array}{c}\text { Number/ } \\
\%\end{array}$ & $\begin{array}{l}\text { Strongly } \\
\text { disagree }\end{array}$ & disagree & neutral & agree & $\begin{array}{l}\text { Strongly } \\
\text { agree }\end{array}$ & \\
\hline $\begin{array}{l}\text { Management } \\
\text { support }\end{array}$ & $\begin{array}{l}\text { The school management } \\
\text { supports this initiative }\end{array}$ & $\begin{array}{c}\text { Number } \\
\%\end{array}$ & $\begin{array}{l}0 \\
0\end{array}$ & $\begin{array}{l}0 \\
0\end{array}$ & $\begin{array}{c}39 \\
48.8\end{array}$ & $\begin{array}{c}18 \\
22.5\end{array}$ & $\begin{array}{c}23 \\
28.7\end{array}$ & 3.800 \\
\hline $\begin{array}{l}\text { Government } \\
\text { support }\end{array}$ & $\begin{array}{l}\text { Malaysia government } \\
\text { encourages eLearning in } \\
\text { Secondary School }\end{array}$ & $\begin{array}{c}\text { Number } \\
\%\end{array}$ & $\begin{array}{l}0 \\
0\end{array}$ & $\begin{array}{l}0 \\
0\end{array}$ & $\begin{array}{c}35 \\
43.8\end{array}$ & $\begin{array}{c}17 \\
21.3\end{array}$ & $\begin{array}{l}28 \\
35\end{array}$ & 3.9125 \\
\hline Resources & $\begin{array}{l}\text { There are rooms available for } \\
\text { internet access in the school }\end{array}$ & $\begin{array}{c}\text { Number } \\
\%\end{array}$ & $\begin{array}{c}14 \\
17.5\end{array}$ & $\begin{array}{c}19 \\
23.8\end{array}$ & $\begin{array}{c}41 \\
51.2\end{array}$ & $\begin{array}{c}3 \\
3.8\end{array}$ & $\begin{array}{c}3 \\
3.8\end{array}$ & 2.5250 \\
\hline & TOTAL & & & & & & & 10.2375 \\
\hline
\end{tabular}

Dimensions. The results indicated that participants agreed with Design, Technology and Support play an important role to ensure the success of EL implementation.

From the results, we infer and accept the alternative hypothesis, $\mathrm{H}_{1}$. In addition, we can observe that the participants believe that Technology has the highest influence on the success of EL implementation. On the other hand, the lack of support, especially on the resources is the main factor hinders the success of EL implementation.

\section{Conclusion and Future Works}

EL may serve as an alternative to traditional teaching in Secondary School. Nevertheless, the implementation of EL may fail should the critical success factors is not identified correctly. This paper materialized the LearnCube, a multi-dimensional conceptual framework for EL, in a pilot study. LearnCube is composed based on correct identification on the stakeholders involved, accurate identification on the critical success factors. 
As our future work, we plan to improve on the questionnaire design for the role out for the actual survey based on this pilot study. Also, other statistical methods such as PLS SEM, or neural network may be employed to explore cause/effect relationship among variables.

\section{References}

1. Sun PC, Tasi RJ, Finger G, Chen YY, Yeh D. What drives a successful e-Learning? An empirical investigation of the critical factors influencing learner satisfaction. Computer and Education. 2008; 50:1183-202.

2. Odunaike SA, Olugbara OO, Ojo SO. E-learning implementation critical success factors. International Multi-Conference of Engineers and Computer Scientists; 2013. p. 560-5.

3. McGill TJ, Klobas JE, Renzi S. Critical success factors for the continuation of e-learning initiatives. The Internet and Higher Education. 2014; 22:24-36.

4. Haw SK, Haw SC, Wong CO, Lim YP. LearnCube: A conceptual framework for e-learning implementation in secondary school. Indian Journal of Science and Technology. 2015; 8(32):1-7.

5. Khan BH. E-learning: A framework for e-learning [Internet]. [cited 2015 Jun 10]. Available from: http://lomo. kyberia.net/diplomovka/webdownload/partial/elearningmag.com/E-Learning\%20-\%20A\%20Framework\%20 for\%20E-learning.pdf.
6. Tirziu AM, Vrabie V. Education 2.0: E-learning methods. Procedia - Social and Behavioral Sciences. 2015; 186: 376-80.

7. Aparicio M, Bacao F, Oliveira T. An e-learning theoretical framework. Educational Technology and Society. 2016; 19(1):292-307.

8. Dabbagh N. Pedagogical models for e-learning: A theory-based design framework. International Journal of Technology in Teaching and Learning. 2005; 1(1):25-44.

9. Thirunarayanan MO, Prado AP. Comparing web based and classroom based learning: A quantitative study. Journal of Research on Technology in Education. 2001; 2:131-7.

10. Greenhow C, Robelia B, Hughes JE. Learning, teaching, and scholarship in a digital age Web 2.0 and classroom research: What path should we take now? Education and Educational Research. 2009; 38(4):246-59

11. Alias N, Siraj S, DeWitt D, Attaran, M. Evaluation on the usability of physics module in a secondary school in Malaysia: Students' retrospective. The Malaysian Online Journal of Educational Technology. 2013; 1(1):44-53.

12. Sekaran U, Bougie R. Research methods for business: A skill-building approach. United Kingdom, Wiley; 2013.

13. Hair JF, Bush RB, Ortinau DJ. Marketing research within a changing information environment. McGraw-Hill; 2003.

14. Dillman DA. Mail and internet survey. The tailored design method. John Wiley \& Sons; 2007. 